\section{Hydrobiologia}

Volume 588, Number 1 / septembre 2007 : 159-172

http://dx.doi.org/10.1007/s10750-007-0660-3

(c) 2007 Springer

The original publication is available at http://www.springerlink.com
Archimer, archive institutionnelle de l'Ifremer http://www.ifremer.fr/docelec/

\title{
Facing the necessity of describing estuarine ecosystems: a review of food web ecology study techniques
}

\author{
Stéphanie Pasquaud ${ }^{1, *}$, Jérémy Lobry $^{2} \&$ Pierre Elie $^{1}$ \\ ${ }^{1}$ CEMAGREF - Groupement de Bordeaux, Unité Ecosystèmes estuariens et Poissons migrateurs amphihalins, 50 \\ Avenue de Verdun, 33612 Cestas, France \\ ${ }^{2}$ IFREMER - Centre de Nantes, Département EMH (Ecologie et Modèles pour l'Halieutique), Rue de I'lle d'Yeu, \\ BP 21105, 44311 Nantes Cedex 3, France \\ *: Corresponding author : stephanie.pasquaud@bordeaux.cemagref.fr
}

\begin{abstract}
:
Estuarine areas are sites of human pressures and degradation. In order to maintain and/or restore the quality of estuarine ecosystems, it is necessary to describe their structure and functioning. For that reason, many recent scientific works focus on food webs, which are depicted as being good indicators of the functioning of aquatic ecosystems. Hence it is necessary to question how estuarine food webs can be described. This paper proposes a pragmatic and practical review of the most widely used techniques (stomach/gut content analysis, stable isotope ratios and biochemical markers) with emphasis on their main advantages, drawbacks and bias according to possible ecological goals (ecological quality objectives). These approaches, although quite different, provide complementary information about the trophic relationships in the system, that is to say the sources of organic matter and the description of energy flows between the different compartments of the food web. In trophic models, all these results can be integrated to a global picture of the estuarine trophic structure. This is considered to be an essential step towards the understanding of the functioning of these ecosystems.
\end{abstract}

Keywords: Estuarine food web - Stomach/gut content analysis - Stable isotope - Biochemical marker - Trophic model 


\section{Introduction}

Because managers are focussing more and more on a regional environment scale, the need for ecosystem-level research has never been more important than now (Livingston, 2002). For fisheries science for instance, Petitgas (2002) commented, in a recent review, that "scientific focus shifted from the management of resources to that of ecosystems, as politicians decided that fisheries and environment issues should be integrated". This situation is probably exacerbated in coastal and estuarine areas where the potential conflicts of interests between users are multiple and where the relations between human activities and biological systems and the conflicts of use between ecological sustainability and economic valuation are acute. The high heritage value of these systems combined with the fact that they are amongst the most productive systems at various levels (Costanza et al., 1997; Day et al., 1981) explains that they constitute a major ecological stake in the way to a sustainable management of aquatic environments.

An important example of this tendency towards ecosystem-level research is the recent European Union Water Framework Directive (EU, 2000), which requires a very well structured approach in protecting aquatic ecosystems and which, because of the lack in required knowledge, implicitly stimulates high integrated aquatic ecological research. Hence, whatever the biological group the aquatic ecologist can be interested in, he must consider it as a part of the entire ecosystem.

Odum (1953) formulated the most widely used definition of an ecosystem as "any entity or natural unit that includes living and nonliving parts interacting to produce a stable system in which the exchange of materials between the living and the nonliving parts follows circular paths is an ecological system or ecosystem”. Estuarine ecosystems are particular ones in which the habitat (abiotic environment) is especially characterized by rapid and intense fluctuations of the physicochemical factors and the biotic communities are characterised by a strong spatial and seasonal heterogeneity and variability (McLusky \& Elliott 2004). Moreover, as these ecosystems are often subjected to important anthropogenic pressures such as fishing, harbour activities, dredging or industrial discharges (Mouny, 1998), their structure and their functioning are the result of natural variations and anthropogenic effects. Describing and understanding these connections is an essential step in order to maintain and to restore the quality of estuarine areas, hence there is the need to consider and review the methods available for describing an estuarine ecosystem.

Assuming like Platt \& Denman (1978) that "the structure of a community of species resulted from trophic interactions", several recent scientific works at the ecosystem level now emphasize food web ecology as central to an understanding of how aquatic systems function (e.g. Ulanowicz, 1986; de Jonge, 1990; Baird et al., 1991; Baird \& Ulanowicz, 1993; Livingston, 2002). These authors put interactions between the different living parts of the system at the heart of ecosystem considerations. This trophodynamic view of the functioning of an ecosystem is mainly inherited from Lindeman's thermodynamical theory of the exchange of materials in an ecological system (Lindeman, 1942).

The above considerations dictate the need to describe the estuarine food web. This can be by characterising trophic relationships between species or groups of species (feeding guilds, functional groups, species which can be separated by sex and size...) i.e. by characterising sources of organic matter and energy flows between the components of the system (West et al. 2003). Whipple et al. (2000) put forward that "Construction, validation and application of models is a useful method to evaluate predation and fisheries mortality and the impacts of these processes on population dynamics". Most of the models tackled by this author, and especially process-based models require qualitative or quantitative data about species interactions in the system and diet compositions of the species included in the 
analysis. So, very local and very relevant studies are often necessary, in particular to describe the trophic regimes of species.

Irrespective of whether the aim is to describe trophic relationships in the system or to "feed" trophic models, stomach/gut content analysis, stable isotopes ratios and biochemical markers such as fatty acids and sterols are amongst the most widely used techniques in food web ecology (Elliott \& Hemingway 2002). The present paper aims at proposing a pragmatic and practical review of these approaches with emphasis on their main advantages, disadvantages and bias according to possible goals being reached by the estuarine ecologist.

\section{Stomach/gut content analysis}

In order to improve the knowledge about the functioning of the fish community in the Tagus estuary (Portugal), Costa (1982; 1988) studied the estuarine food web and she described the diet composition and the feeding ecology of the most abundant fish species using stomach/gut content analysis.

This method is considered as a "standard practice" in fish and marine vertebrates ecology (Hyslop, 1980; Cortés, 1997) and is also used for the study of crustacean ecology (e.g. Sorbe, 1983; David, 2001). It consists in the direct observation of the stomach contents providing information on what and how much an animal has recently eaten (Costa, 1982; Elie \& Marchand, 1983; Marshall, 1995; David, 2001; Elliott \& Hemingway, 2002). For some species, such as the gobies, all the gut content is analysed (e.g. Pasquaud et al., 2004) because they do not have a functional sphincter between the stomach and the intestine (Bertin, 1958). Typically, such method involves catching, killing and dissecting many organisms (Elliott \& Hemingway, 2002). But it is sometimes possible to capture and anaesthetise the animal and then to flush out the stomach contents without causing any harm (e.g. stomach-flushing technique; Strange \& Kennedy, 1981). This provides valuable data especially when applied to endangered and rare species (e.g. European sturgeon; Brosse et al., 2000).

In the laboratory, all food items are identified to the highest possible taxonomic separation (providing a qualitative description), counted and weighted (giving quantitative information). In some cases, a volumetric approach can be preferred to the gravimetric technique (e.g. West et al., 2003). The calculation of simple indexes such as frequency of occurrence, percent composition by number, by weight or by volume allows for the precise characterisation of diet (Marshall \& Elliott 1997). The validity, reliability and practicability of different methods for the investigation of stomach contents, especially for fish, have been discussed to a large extent by several authors (Swynnerton \& Worthington, 1940; Hynes, 1950; Pillay, 1950; Windell \& Bowen, 1968; Hellawell \& Abel, 1970; Hureau, 1970; Berg, 1979; Hyslop, 1980; Wootton, 1990; Cortés, 1997; Hansson, 1998).

Standard statistical tests and univariate/multivariate numerical and/or graphical techniques (Clarke, 1993; Marshall \& Elliott, 1997; Elliott \& Hemingway, 2002) are often used in order to go from a simple knowledge of trophic ecology to a valuable understanding of the dynamic feeding relationships.

These approaches provide pictures of the intra- and interspecific relationships (Costa, 1982; Elie \& Marchand, 1983; Henderson et al., 1992; Marshall, 1995; David, 2001) and allow us to characterise the trophic guilds (e.g., Baldo \& Drake, 2002, Hajisamae et al.; 2003; Fig. 1) and the major trophic levels (e.g., Henderson et al., 1992; West et al., 2003; Fig. 2).

Among its main advantages, the technique seems to be an interesting way to study the spatial and seasonal variability of parts of food webs (Costa, 1982; Henderson et al., 1992; Marshall, 1995; Hajisamae et al., 2003; West et al., 2003), which is a major problem in understanding the functioning of estuaries. Moreover, this method allows us to look for 
changes in the diet of species related to size and ontogeny (Baldo \& Drake, 2002; Marshall, 1995; Elie \& Marchand, 1983).

In absolute terms, these data analyses enable a relatively good description of the fish and some crustaceans diet, qualitatively and quantitatively (Bowen, 1996). But this approach is less used because of the required intensity sampling and the bias of the method, which reduces the representativeness of the results (Elliott \& Hemingway, 2002). Indeed, bias and difficulties must be taken into account. In addition to the classical problem with sampling design in space and time depending on the questions at that level, it is important to note that, for instance, care should be taken with sampling to minimize regurgitation, feeding under abnormal conditions (due to the use of trawl or trap), digestion after capture (variable according to species) and daily or tidal bias between samples (Potts \& Reay, 1987). Furthermore, it is of note that the calculation of diet indices is dependent on the ease of identification of the food organisms (Marshall \& Elliott, 1997). "However, proportions of food found in the stomach are unlikely to reflect exact proportions ingested due to differential rates of digestion of different types of prey taxa" (Elliott \& Hemingway, 2002). Indeed, the importance of rapidly digested prey items may be underestimated and the importance of less digestable prey is overestimated (Hyslop, 1980), resulting in a bias in prey analysis. Hence, these aspects require to be quantified during the analysis. Moreover, the identification of prey is sometimes difficult, because of their level of degradation due to digestion again, which is certainly the major bias of the method.

This approach is difficult to apply on small organisms (David, 2001) and some compartments such as zooplankton cannot be investigated using this technique. Conversely, it is mainly used and well adapted for fish (Hynes, 1950; Berg, 1979; Hyslop, 1980; Elliott \& Hemingway, 2002). Consequently, stomach content analyses are unlikely to provide a complete understanding of the estuarine food web (e.g., Henderson et al., 1992; Hajisamae et al., 2003; Fig. 1) and so other complementary methods, such as isotopic analysis, considering mainly the first components of the estuarine trophic webs must be employed (e.g. West et al., 2003).

\section{Stable isotopes: $\delta^{15} \mathrm{~N}, \delta^{13} \mathrm{C}, \delta^{34} \mathrm{~S}$}

In a study designed to identify organic matter sources that support consumers and to seek trophic linkages in different wetlands, Kwak \& Zedler (1997) used carbon, nitrogen and sulfur stable isotopes to characterize the food web in Tijuana estuary (Southern California). This method appears to be a good tool to improve our understanding of the basis of the estuarine food web, especially regarding which sources of organic matter in general provide energy and nutrient resources to heterotrophs and through which organisms this energy is transferred (DeNiro \& Epstein, 1978; Fry \& Sherr, 1984; Cloern et al., 2002). This method is based on the spectrophotometric measurment of the isotopic ratios of light elements (carbon, nitrogen and sulfur).

The analysis of stable carbon isotopes $\left(\delta^{13} \mathrm{C}\right)$ in suspended particulate organic matter and sediments can indicate the origins of plant source materials (e.g., Fry \& Sherr, 1984). In an estuarine ecosystem, there are several potential sources of carbon with different $\delta^{13} \mathrm{C}$ signatures. These characteristic isotopic ratios are preserved in the consumers and are propagated along the food chain. So, the composition of stable carbon isotopes in an organism corresponds to the integration of the different food resource(s) consumed during a certain time in a given area (DeNiro \& Epstein, 1978, 1981; Wada et al., 1991; Dufour \& Gerdeaux, 2001) and provides the relative contributions of some groups of primary producers (Maberly et al., 1992). Because of this, $\delta^{13} \mathrm{C}$ is a good indicator of the diet composition in the primary consumers; however, because of the weak difference in $\delta^{13} \mathrm{C}$ between an animal and its food, 
$\delta^{13} \mathrm{C}$ is not very indicative of the trophic level (Davenport \& Bax, 2002). Consequently, analyses of stable nitrogen isotopes $\left(\delta^{15} \mathrm{~N}\right)$ are also used to provide information on source materials (e.g., France, 1994) but are especially used to determine trophic levels and to deduce relationships between the primary producers and the primary consumers in an ecosystem. Indeed, the relatively large difference in $\delta^{15} \mathrm{~N}$ between an animal and its prey allows trophic relationships and levels within an ecosystem to be estimated by characterising the diet composition of the animal (Minagawa \& Wada, 1984; Wada et al., 1987; Fry, 1988; Kwak \& Zedler, 1997; Wada et al., 1991; Lesage et al., 2001). Finally, the sulfur isotopic ratio may also be measured and even if the use of this element is less precise than the carbon, it provides a good marker for tracing the origins of organic matter (Deegan \& Garritt, 1997).

Multiple stable isotope comparisons (dual isotope plots of $\delta^{15} \mathrm{~N}, \delta^{13} \mathrm{C}$ and $\delta^{34} \mathrm{~S}$; Jassby et al., 1993; Deegan \& Garritt, 1997; Jassby \& Cloern, 2000) provide significantly more power to resolve food web structure than does a single isotope approach (Fry \& Scherr, 1984; Peterson et al., 1985; e.g., Lesage et al., 2001; Fig. 3). They constitute a valuable approach to evaluate the complexity of the food web (Kwak \& Zedler, 1997).

In recent years, the interest in the use of stable isotopes of the organic matter in order to study the architecture of the aquatic food webs has increased (Deegan \& Garritt, 1997). Their application has become a powerful tool for identifying food web linkages (Wada et al., 1991) in rivers (Finlay, 2001), flood plains (Lewis et al., 2001), salt marshes (Currin et al., 1995), lakes (Kling et al., 1992; Vander Zander \& Rasmussen, 1999) and marine systems (Michener \& Schell, 1994).

In estuaries, Kwak \& Zelder (1997) used stable isotope studies to determine the sources of organic matter in suspended particulate organic matter and sediments and to follow them in primary consumers (see also Paterson \& Whitfield, 1997; Wada et al., 1991). The seasonal and/or spatial variabilities of these sources can be evaluated (Deegan \& Garritt, 1997; Ruesink et al., 2003; Kwak \& Zedler, 1997; Riera et al., 2000; Cloern et al., 2002). Thus, this approach is a complementary technique to stomach content analysis, by defining the basis of food webs (Kwak \& Zedler, 1997; West et al., 2003). In particular, the feeding ecology of organisms which are too small to be investigated by the observation of their diet, can be determinated. Thus the planktonic (Perissinotto et al., 2003) and meiobenthic food webs (Carman \& Fry, 2002) can be obtained. Furthermore, this technique offers a unique way to study detrital food webs which are fundamental to the functioning of estuaries (Peterson \& Fry, 1987; McLusky \& Elliott 2004). Moreover, this approach provides a more representative description of relative trophic levels of each species than that provided by stomach content analyses (e.g., Kwak \& Zedler, 1997; West et al., 2003; Fig. 3). Hence the isotopic ratios can characterise the basis of food webs and determine the trophic levels but, for example, they also can describe the variability of the fish and marine mammals' diet with age and sex (e.g., Lesage et al., 2001).

It may be difficult, using the above method, to describe the whole estuarine food web and the space-time variability of the trophic network because of the strong space-time heterogeneity of the ecosystem, in particular fish/mammal communities, which leads to the integration of a signal during a certain temporal scale (Hesslein et al., 1991; Hessein et al., 1993; Dufour \& Gerdeaux, 2001; Perga, 2004) including periods when individuals are not in the estuary (e.g. Bardonnet \& Riera, 2004). Furthermore, the method may have the problem in that the isotopic signatures of the various sources of organic matter (the contribution of the river basin area, of the resident source or of littoral marine origin) are often superimposed in these so complex and fluctuating systems (Kwak \& Zedler, 1997; Cloern et al., 2002) making it difficult to identify the diet. However, the isotopic composition of consumers is useful to complement other biomarkers, such as fatty acids and sterols (e.g. Canuel et al., 1997; Shi et al., 2001). 


\section{Biochemical markers: fatty acids, sterols}

Kwak \& Zedler (1997) highlighted the difficulty of categorizing food webs using stable isotope techniques in fluctuant systems. Thus, in order to investigate trophic relationships between phytoplankton blooms and the major local primary consumers in the Bahia Blanca estuary (Argentina), Napolitano et al. (1997) used lipids as biochemical makers.

Lipids are a heterogeneous group of molecules involved in many vital functions in aquatic organisms (Sargent, 1976). Among them, fatty acids and sterols are synthesized in a specific way by certain groups of organisms (e.g., Canuel et al., 1995; Napolitano et al., 1997) and they are transferred unchanged (or in a recognizable form) to the upper levels of food webs (Napolitano et al., 1997). Hence,these constituents have proved to be important tools firstly in the detection of the origin of the organic matter (Saliot et al., 1991; Canuel et al., 1995) in suspended material (Currie \& Johns, 1988), in sediment (Volkman et al., 1980; Fichez et al., 1993; Rajendran et al., 1993; Meziane et al., 1997) and in macrozoobenthos (Nichols et al., 1982; Kharlamento et al., 1995) but also in clarifying the trophic relationships (Sargent \& Whittle, 1981; Kharlamenko et al., 1995).

For example, as some lipidic constituents (in particular essential fatty acids), which are produced by plants, cannot be synthesized de novo by primary consumers, they constitute particularly useful trophic markers because they are synthesized by plants and selected bacteria and are then assimilated and retained by animals (Napolitano et al., 1997). In an estuarine ecosystem, there are many fatty acids and sterols found in the organic matter and they have different origins (estuarine, marine or riverine continental phytoplankton, terrestrial plants) (Thoumelin et al., 1997; Bodineau et al., 1998). Because of their structure, these different lipidic constituents are easily recognizable and so they provide an effective means to detect and identify the different sources of organic matter. This method can complement isotopic analysis as it gives more precise qualitative information about the source of organic matter (Fichez et al., 1993; Canuel et al., 1995; Shi et al., 2001) but no quantitative values. Conversely, these fatty acids and sterols are also quite well detected in the primary consumers. Thus, this technique allows the identification of the primary producers - primary consumers trophic relationships (Napolitano et al., 1997) and the evaluation of their seasonal and spatial variability (Canuel et al., 1995; Shi et al., 2001). Despite this, these biomarkers are more or less transformed/metabolized in a way that is not very clear in the higher trophic levels thus making it difficult to characterize food webs using these biomarkers.

\section{Discussion}

\section{Trophic models and their data requirements}

With the necessity to synthesize and to improve our knowledge about the trophic structure of estuarine ecosystems, new techniques to describe and quantify organic matter flows have appeared with the development of data-processing and interpretative tools such as trophic models (e.g., Wolff et al., 2000; Fig. 4). Among the spectrum of representative models (see for instance Shin, 2000 or Whipple et al., 2000 for a literature review), steady-state and dynamic process-based models (fig. 5) provide for the most explicit representation of trophic interactions between species. In particular, in inverse analysis (Vézina \& Platt, 1988; Vézina, 1989; Vézina \& Pace, 1994) and Ecopath models (Polivina, 1984; Christensen \& Pauly, 1992; Ulanowicz, 1993), two of the main static approaches in modelling trophic flows, the ecosystem is generally divided in different compartments, or "functional groups", connected by a trophic relationship or a biomass flow. Modelling can be achieved after the 
determination of the space-time limits of the studied system. More details about the energy flows in the system (distribution, circulation) and the thermodynamic state of the system can be obtained by using the principles of network analysis as defined by Ulanowicz (1986). Ecopath analysis accounts for predator-prey relationships and fishery harvest and provides a quantitative assessment of the trophic flows and the trophic structure of the ecosystem. The main assumption (but also the main limitation) of the technique is that the system is massbalanced which allows only for static representation of the food web. Moreover, the model needs a large amount of data to solve the set of linear equations on which the model is constructed. Quantitative diet compositions of the different compartment are typically among the least well-known and the most uncertain parameters needed to balance the model (Kavanagh et al., 2004). Data at various levels can be used because explicit quantitative data describing how much one compartment feeds on the others are not as easy to obtain for all the compartments. That is especially true for estuarine and coastal ecosystems where recent modelling approach have shown that food web ecology is complex, variable and trophic spectrum are quite wide (see for instance Baird et al., 1991; Baird \& Ulanowicz, 1993; Baretta \& Ruardij, 1988; Monaco \& Ulanowicz, 1997; Rybarczyk \& Elkaim, 2003 and Lobry, 2004).

\section{The main advantages and limitations of the methods}

As indicated here, the stomach/gut content analyses, the stable isotopes ratios $\left(\delta^{15} \mathrm{~N}\right.$, $\delta^{13} \mathrm{C}, \delta{ }^{34} \mathrm{~S}$ ) and the biochemical markers such as fatty acids and sterols are the three main techniques used in food web ecology. The main limitations and difficulties with the above techniques in estuaries come from the fact that estuaries are transitory habitats for many species and especially for fish species (Elliott \& Dewailly, 1995; Elliott \& Hemingway, 2002; Lobry et al., 2003). That supposes there are multiple sources of organic matter and that preys can have riverine and/or marine signals. Thus, this underlines the great importance of a relevant sampling design in space and time.

Table I that summarises the advantages and disadvantages of each technique and shows that these methods present different and complementary information in order to describe estuarine ecosystems. Indeed, firstly, the stomach/gut content analysis appears like the most reliable method of studying the fish estuarine food webs. Secondly, the study of stable isotopes ratios allows us to determine the trophic levels and, thirdly, coupled with the investigation of biochemical markers, it provides a good representation of the basic structure of food webs. Hence, as would be expected, the method chosen depends on the aims, objectives and hypotheses generated by a study. However, in most estuaries, the food webs are based on the "detritus" component from both allochthonous and autochthonous complex and variable sources (Lobry, 2004; McLusky \& Elliott 2004). In those cases, the use of stable isotope ratios and biochemical markers has limitations because of such processes as physical, chemical and biological degradation. The isotopic signals are always superimposed and the lipids constituents are often in an unrecognisable form. This makes the characterization of the origin of the organic matter and thus, the basis of the food webs a difficult task.

It is concluded here that even if the stomach contents analyses do not provide information about the origin of the detritic organic matter and even if the analysis is sometimes very constrained, for example with the identification of the phytoplankton and the very digested and unidentifiable items, this method appears to be the most reliable in order to improve the knowledge of the estuarine food webs. Hence the conclusion by Elliott \& Hemingway (2002) that the information derived from stomach contents analysis can be used primarily to create and quantify food webs, to investigate the feeding behaviour and resource partitioning and to estimate energy budgets. Thus, an adequate picture of the food webs is 
obtained and the data can be employed for trophic models, which allow us to predict spacetime variations of the predator-prey relationships, to simulate contaminations by pollutants through food webs and to compare the different estuarine trophic structures.

Although the characterization of the trophic webs remains both challenging and with inherent errors dictated by the methods used, it represents an essential step in the determination of the functioning of an ecosystem. For example, knowing the food web structures allows us to start to explain succession patterns, to detect the possible anomalies in the evolution of certain components of the populations and to understand bioavailaibility and biomagnification xenobiotic and other polluting substances. In addition, they will contribute to provide a tool in defining Good Ecological Status, determining indicators and comparing deterioration against reference sites as required by the recently adopted European Union Water Framework Directive.

\section{Acknowledgements}

The authors would like to thank their colleagues of the Cemagref, Michel Girardin and Mario Lepage, for their advices and their support. They would particularly thank Isabelle Ortusi and Prof. Mike Elliott (University of Hull, U.K.) for checking the English.

\section{References}

Baird, D., McGlade, J.M. \& R.E. Ulanowicz., 1991. The Comparative Ecology of 6 Marine Ecosystems. Philosophical Transactions of the Royal Society of London Series B-Biological Sciences 333: 15-29.

Baird, D. \& R.E. Ulanowicz, 1993. Comparative-Study on the Trophic Structure, Cycling and Ecosystem Properties of 4 Tidal Estuaries. Marine Ecology-Progress Series 99: 221-237.

Baldo, F. \& P. Drake, 2002. A multivariate approach to the feeding habits of small fishes in the Guadalquivir Estuary. Journal of Fish Biology 61: 21-32.

Bardonnet, A. \& P. Riera, 2005. Feeding of glass eels (Anguilla anguilla) in the course of their estuarine migration: new insights from stable isotope analysis. Estuarine, Coastal and Shelf Science 63(1-2): 201-209.

Baretta, J.W. \& P. Ruardij (eds), 1988. Tidal flat estuaries: simulation and analysis of the Ems estuary, Ecological Studies 71. Berlin, Germany, Springer Verlag: 353 pp.

Berg, J., 1979. Discussion of Methods of Investigating the Food of Fishes, with Reference to a Preliminary Study of the Prey of Gobiusculus flavescens (Gobiidae). Marine Biology 50: 263-273.

Bertin L., 1958. Appareil digestif. In Grassé, P.P. (ed), Traité de zoologie. Masson \& Cie, Paris: 1967-1983.

Bodineau, L., G. Thoumelin, V. Béghin, \& M. Wartel, 1998. Particule organic matter composition in the Estuarine Turbidity Maxima (ETM) of the Seine River estuary. Hydrobiologia 373/374: 281-295.

Bowen, S.H., 1996. Quantitative Description of the Diet. In Murphy, B.R. \& D.W. Willis (eds), Fisheries Techniques American Fisheries Society. Bethesda, Maryland: 513-532.

Brosse L., P. Dumont, M. Lepage \& E. Rochard, 2002. Evaluation of a gastric lavage method for sturgeons. North American Journal of Fisheries Management 22(3): 955-960. 
Canuel, E.A., J.E. Cloern, D.B. Ringelberg, J.B. Guckert \& G.H. Rau, 1995. Molecular and isotopic tracers used to examine sources or organic matter and its incorporation into the food webs of San Francisco bay. Limnology and Oceanography 40: 67-81.

Carman, K.R. \& B. Fry, 2002. Small-sample methods for delta C-13 and delta N-15 analysis of the diets of marsh meiofaunal species using natural-abundance and tracer-addition isotope techniques. Marine Ecology Progress Series 240: 85-92.

Christensen, V. \& D. Pauly, 1992. ECOPATH II - a software for balancing steady-state ecosystem models and calculating network characteristics. Ecological Modelling 61: 169-185.

Clarke, K.R., 1993. Non-parametric multivariate analyses of changes in community structure. Australian Journal of Ecology 18: 117-143.

Cloern, J.E., E.A. Canuel \& D. Harris, 2002. Stable carbon and nitrogen isotope composition of aquatic and terrestrial plants of the San Francisco Bay estuarine system. Limnology and oceanography 47: 713-729.

Cortés, E., 1997. A critical review of methods of studying fish feeding based on analysis of stomach contents: application to elasmobranch fishes. Canadian Journal of Fisheries and Aquatic Sciences 54: 726-738.

Costa, M.J., 1982. Contribution à l'étude de l'écologie des poissons de l'estuaire du Tage (Portugal). PhD Thesis, Université de Paris VII: 256 p.

Costa, M.J., 1988. Ecologie alimentaire des poissons de l'estuaire du Tage. Cybium 12: 301320.

Costanza, R., R. D'Arge, R. De Groot, S. Farber, M. Grasso, B. Hannon, K. Limburg, S. Naeem, R.V. O'Neill, J. Paruelo, R.G. Raskin, P. Sutton, \& M. Van den Belt, 1997. The value of the world's ecosystem services and natural capital. Nature 387: 253-260.

Currie, B.R. \& R.B. Johns, 1988. Lipids as indicators of the origin of organic matter in fine marine particular matter. Australian Journal of Marine and Freshwater Research 39: 371-383.

Currin, C.A., S.Y. Newell \& H.W. Paerl, 1995. The role of standing dead Spartina alterniflora and benthic microalgae in salt-mash food webs: considerations based on multiple stable isotope analysis. Marine Ecology Progress Series 121: 99-116.

Davenport, S.R. \& N.J. Bax, 2002. A trophic study of a marine ecosystem off southeasten Australia using stable isotopes of carbon and nitrogen. Canadian Journal of Fisheries and Aquatic Sciences 59: 514-530.

David, V., 2001. Réseau trophique zooplanctonique dans l'estuaire de la Gironde: caractérisation et modélisation de la relation mysidacés-copépodes. DEA, Université de Bordeaux I, Bordeaux.

Day, J.H., Blaber, S.J.M. \& J.H.Wallace, 1981. Estuarine fishes. In: Day JH (ed) Estuarine ecology with particular reference to Southern Africa, Balkena, Cape Town, pp 197-221.

Deegan, L.A. \& R.H. Garritt, 1997. Evidence for spatial variability in estuarine food webs. Marine ecology process series 147: 31-47.

de Jonge, V.N., 1990. Responses of the Dutch Wadden Sea ecosystem to phosphorus discharges from the River Rhine. Hydrobiologia 195: 49-62.

DeNiro, M.J. \& S. Epstein, 1978. Influence of diet on the distribution of carbon isotopes in animals. Geochimica et Cosmochimica Acta 42: 495-506. 
DeNiro, M.J. \& S. Epstein, 1981. Influence of diet on the distribution of nitrogen isotopes in animals. Geochimica et Cosmochimica Acta 45: 341-351.

Dufour, E. \& D. Gerdeaux, 2001. Apports des isotopes stables $\left({ }^{13} \mathrm{C} /{ }^{12} \mathrm{C},{ }^{15} \mathrm{~N} /{ }^{14} \mathrm{~N},{ }^{18} \mathrm{O} /{ }^{16} \mathrm{O}\right.$, ${ }^{36} \mathrm{~S} /{ }^{34} \mathrm{~S},{ }^{87} \mathrm{Sr} /{ }^{86} \mathrm{Sr}$ ) aux études écologiques sur les poissons. Cybium 25: 369-382.

Elie, P. \& J. Marchand, 1983. Contribution à l'étude des ressources bentho-démersales de l'estuaire de la Loire : biologie et écologie des principales espèces. CSEEL/Ministère de l'Environnement/Ministère de la Mer, Nantes.

Elliott, M. \& F. Dewailly, 1995. The structure and components of European estuarine fish assemblages. Netherlands Journal of Aquatic Ecology 29(2-3): 397-417.

Elliott, M. \& K. Hemingway, 2002. Fishes in Estuaries. Blackwells, London: 636 pp.

E.U., 2000. Parliament and Council Directive 2000/60/EC of 23rd October 2000. Establishing a Framework for Community Action in the field of Water Policy. Official Journal PE-CONS 3639/1/00 REV 1, Brussels.

Fichez, R., P. Dennis, M.F. Fontaine \& T.D. Jickells, 1993. Isotopic and biochemical composition of particulate organic matter in a shallow-water estuary (Great Ouse, North-sea, England). Estuarine Organic Process 43: 263-276.

Finlay, J.C., 2001. Stable-carbon-isotope ratios of river biota: Implications for energy flow in lotic food webs. Ecology 82: 1052-1064.

France, R.L., 1994. Nitrogen isotopic composition of marine and freshwater invertebrates. Marine Ecology Progress Series 115: 205-207.

Fry, B., 1988. Food web structure on George bank from stable C, N, and S isotopic compositions. Limnology and Oceanography 33: 1182-1190.

Fry, B. \& E.B. Sherr, 1984. $\delta 13 \mathrm{C}$ measurements as indicators of carbon flow in marine and freshwater ecosystems. Contributions in Marine Science 27: 13-47.

Hajisamae, S., L.M. Chou \& S. Ibrahim, 2003. Feeding habits and trophic organization of the fish community in shallow waters of an impacted tropical habitat. Estuarine, Coastal and Shelf Science 58: 89-98.

Hansson, S., 1998. Methods of studying fish feeding: a comment. Canadian Journal of Fisheries and Aquatic Sciences 55(12): 2706-2707.

Hellawell, J.M. \& R. Abel, 1971. A rapid volumetric method for the analysis of the food of fishes. Journal of Fish Biology 3: 29-37.

Henderson, P.A., D. James \& R.H.A. Holmes, 1992. Trophic Structure within the Bristol Channel - Seasonality and Stability in Bridgwater Bay. Journal of the Marine Biological Association of the United Kingdom 72: 675-690.

Hesslein, R.H., M.J. Capel, D.E. Fox \& K.A. Hallard, 1991. Stable isotopes of sulfur, carbon and nitrogen as indicators of trophic level and fish migration in the lower Mackenzie river basin, Canada. Canadian Journal of Fisheries and Aquatic Sciences 48: 1991-2001.

Hesslein, R.H., K.A. Hallard \& P. Ramlal, 1993. Replacement of sulfur, carbon and nitrogen in tissue of growing broad Whitefish (Coregonus nasus) in response to a change in diet traced by delta 34S, delta 13C and delta 15N. Canadian Journal of Fisheries and Aquatic Sciences 50: 2071-2076.

Hureau, J.-C., 1970. Biologie comparée de quelques poissons antarctiques (Nototheniidae). Bulletin de l'Institut Océanographique de Monaco 68: 139-164. 
Hynes, H.B.N., 1950. The food of freshwater sticklebacks (Gasterosteus aculeatus and Pygosteus pungitius) with a review of methods used in studies of the food of fishes. Journal of Animal Ecology 19: 36-58.

Hyslop, E.J., 1980. Stomach contents analysis - a review of methods and their application. Journal of Fish Biology 17: 411-429.

Jassby, A.D. \& J.E. Cloern, 2000. Organic matter sources and rehabilitation of the Sacramento-San Joaquin Delta (California, USA). Aquatic conservation - Marine and Freswater Ecosystems 10: 323-352.

Jassby, A.D., J.E. Cloern \& T.M. Pawell, 1993. Organic-carbon sources and sinks in SanFransco Bay - variability induced by river flow. Marine Ecology-Progress Series 95: 39-54.

Kavanagh, P., N. Newlands, V. Christensen \& D. Paul, 2004. Automated parameter optimization for Ecopath ecosystem models. Ecological Modelling 172: 141-149.

Kharlamenko, V.I., N.V. Zhukova, S.V. Khotimchenko, V.I. Svetashev \& G.M. Kamenev, 1995. Fatty acids as makers of food sources in a shallow-water hydrothermal ecosystem (Kraternaya Bight, Yankich Island, Kurile Islands). Marine Ecology Progress Series 120: 231241.

Kling, G.W., B. Fry \& W.J. O'Brien, 1992. Stable isotopes and planktonic structure in Arctic lakes. Ecology 73: 561-566.

Kwak, T. \& J.B. Zedler, 1997. Food web analysis of southern California coastal wetlands using multiple stable isotopes. Oecologia 110: 262-277.

Lesage, V., M.O. Hammill \& K.M. Kovacs, 2001. Marine mammals and the community structure of the estuary and Gulf of St Lawrence, Canada: Evidence from stable isotope analysis. Marine Ecology Progress Series 210: 203-221.

Lewis, W.M., S.K. Hamilton, M.A. Rodriguez, J.F. Saunders \& M.A. Lasi, 2001. Food web analysis of the Orinoco floodplain based on production estimates and stable isotope data. Journal of the North American Benthological Society 202: 241-254.

Lindeman, R.L., 1942. The trophic-dynamic aspect of ecology. Ecology 23: 399-418.

Livingston, R.J., 2002. Trophic organization in coastal systems, CRC Press.

Lobry, J., L. Mourand, E. Rochard \& P. Elie, 2003. Structure of the Gironde estuarine fish assemblages: a European estuaries comparison perspective. Aquatic Living Resources 16(2): 47-58.

Lobry, J., 2004. "Quel référentiel de fonctionnement pour les écosystèmes estuariens ? " - Le cas des cortèges de poissons fréquentant l'estuaire de la Gironde. PhD thesis, Univerity of Bordeaux I: 204 p.

Maberly, S.C., J.A. Raven \& A.M. Johnston, 1992. Discrimination between ${ }^{12} \mathrm{C}$ and ${ }^{13} \mathrm{C}$ by marine plants. Oecologia 91: 481-492.

Marshall, S., 1995. The structure and the functioning of the fish assemblage of the Humber estuary, UK. PhD Thesis, University of Hull, UK.

Marshall, S. \& M. Elliot, 1997. A comparison of univariate and multivariate numerical and graphical techniques for determining inter- and intraspecific feeding relationships in estuarine fish. Journal of Fish Biology 51: 526-545.

Mc Lusky, D.S. \& M. Elliott, 2004. The Estuarine Ecosystem: ecology, threats and management. Oxford University Press, Oxford. 
Meziane, T., L. Bodineau, C. Retere \& G. Thoumelin, 1997. The use of lipid markers to define sources of organic matter in sediment and food web of the intertidal salt-marsh-flat ecosystem of Mont-Saint-Michel Bay, France. Journal of Sea Research 38: 47-58.

Michener, R.H. \& D.M. Schell, 1994. Stable isotope ratios as tracers in marine aquatic food webs. In Ladjtha, K. \& R.H. Michener (eds), Stable isotopes in ecology and environmental science. Blackwell: 138-157.

Minagawa, M. \& E. Wada, 1984. Stepwise enrichment of ${ }^{15} \mathrm{~N}$ along food chains: further evidence and the relation between $\delta^{15} \mathrm{~N}$ and animal age. Geochimica et Cosmochimica Acta 48: 1135-1140.

Monaco, M.E. \& R.E. Ulanowicz, 1997. Comparative ecosystem trophic structure of three US mid- Atlantic estuaries. Marine Ecology-Progress Series 161: 239-254.

Mouny, P., 1998. Structure spatio-temporelle du zooplancton et du supra benthos de l'estuaire de la Seine. Dynamique et rôle des principales espèces dans la chaîne trophique pélagique. PhD Thesis, University of Paris: Museum National d'Histoire Naturelle. 239 p.

Napolitano, G.E., R.J. Pollero, A.M. Gayoso, B.A. MacDonald \& R.J. Thompson, 1997. Fatty acids as trophic markers of phytoplankton blooms in the Bahia Blanca estuary (Buenos Aires, Argentina) and in Trinity Bay (Newfoundland, Canada). Biochemical Systematics and Ecology 25: 739-755.

Nichols, P.D., R.B. Johns \& D.W. Klump, 1982. Study of food chains in seagrass communities, 1. Lipid components of the seagrasses Posidonia australis and Heterozostera tasmanica as indicators of carbon source. Phytochemistry 21: 1613-1621.

Odum, E.P., 1953. Fundamentals of ecology. W.B. Saunders Company, Philadelphia, PA: 384 pp.

Pasquaud, S., M. Girardin \& P. Elie, 2004. Etude du régime alimentaire des gobies du genre Pomatoschistus ( $P$. microps et $P$. minutus) dans l'estuaire de la Gironde (France). Cybium 28(1): 99-106.

Paterson, A.W. \& Whitfield, A.K., 1997. A stable carbon isotope study of the food web in a freshwater-deprived South African estuary, with particular emphasis on the ichthyofauna. Estuarine, Coastal and Shelf Science 45: 705-715.

Perissinotto, R., C. Nozais, I. Kibirige \& A. Anandraj, 2003. Planktonic food webs and benthic-pelagic coupling in three South African temporarily-open estuaries. Acta Oecologica 24: S307-S316.

Perga, M.E., 2004. Origines et flux de carbone dans les réseaux trophiques lacustres : Etude par analyse de la composition en isotopes stables du carbone et de l'azote du zooplancton et des poissons. PhD Thesis, Université de Savoie. 198 p.

Peterson, B.J. \& B. Fry, 1987. Stable isotopes in ecosystem studies. Annual Review of Ecology and Systematics 18: 293-320.

Peterson, B.J., R.W. Howarth \& R.H. Garritt, 1985. Multiple stable isotopes used to trace the flow of organic matter in estuarine food webs. Science 227: 1361-1363.

Petitgas, P., 2002. Modelling in fisheries assessments. In Petitgas, P. (ed), ICES Cooperative Research Report: 16-23

Pillay, T.V.R., 1952. A critique of the methods of study of food of fishes. Journal of the Zoological Society of India 4: 185-200. 
Platt, T. \& K. Denman, 1978. The structure of pelagic marine ecosystems. Rapports et procèsverbaux des réunions CIEM 173: 60-65.

Polovina, J.J., 1984. Model of a coral reef ecosystem. The Ecopath model and its application to French Frigate Shoals. Coral Reefs 3:1-11.

Potts, G.W. \& P.J. Reay, 1987. Fish. In Baker, J. \& W. Wolff (eds), Biological Surveys of Coasts and estuaries. Cambridge University Press, Cambridge: 342-373.

Rajendran, N., Y. Suwa \& Y. Urushigawa, 1993. Distribution of phospholipid ester-linked fatty acid biomarkers for bacteria in the sediment of Ise Bay, Japan. Marine Chemistry 42: 3956.

Riera, P., L.J. Stal \& J. Nieuwenhuize, 2000. Heavy $\delta^{15} \mathrm{~N}$ in intertidal benthic algae and invertebrates in the Scheldt estuary (The Netherlands): Effect of river nitrogen inputs. Estuarine, Coastal and Shelf Science 51: 365-372.

Ruesink, J., G.C. Roegner, B.R. Dumbauld, J.A. Newton \& D.A. Armstrong, 2003. Contributions of coastal and watershed energy sources to secondary production in a Northeastern Pacific estuary. Estuaries 26: 1079-1093.

Rybarczyk, H. \& B. Elkaim, 2003. An analysis of the trophic network of a macrotidal estuary: the Seine Estuary (Eastern Channel, Normandy, France). Estuarine, Coastal and Shelf Science 58: $775-791$.

Saliot, A., J.C. Marty, P. Scribe, M.A. Sicre, T.C. Viets, J.W. Deleeuw, P.A. Schenck \& J.J. Boon, 1991. Characterization of particulate organic matter in mediterranean sea-surface films and underlying water by flash pyrolysis and gas-chromatographic analyses. Organic Geochemistry 17: 329-340.

Sargent, J.H. \& K.J. Whittle, 1981. Lipids and hydrocarbons in the marine food web. In Longhurst, A. (ed), Analysis of Marine Ecosystems. Academic Press, New York: 491-533.

Sargent, J.R., 1976. The structure, metabolism and function of lipids in marine organisms. In Malins, D. \& J.R. Sargent (eds), Biochemical and Biophysical Perspectives in Marine Biology. Academic Press, New York: 149-212.

Shi, W., M.Y. Sun, M. Molina \& R.E. Hodson, 2001. Variability in the distribution of lipid biomarkers and their molecular isotopic composition in Altamaha estuarine sediments: implications for the relative contribution of organic matter from various sources. Organic Geochemistry 32: 453-467.

Shin, Y.J., 2000. Interactions trophiques et dynamiques des populations dans les écosystèmes marins exploités. Approche par modélisation individus-centrée. PhD thesis, Université de Paris VII. 245 p.

Sorbe, J.C., 1983. Les décapodes natantia de l'estuaire de la Gironde (France). Contribution à l'étude morphologique et biologique de Palaemon longirostris. H. Milne Edwards, 1837. Crustaceana 44(3): 251-270.

Strange, C.D. \& G.J.A. Kennedy, 1981. Stomach flushing of salmonids: a simple and effective technique for the removal of the stomach contents. Fisheries Management 12: 9-16.

Swynnerton, G.H. \& E.B. Worthington, 1940. Note on the food of fish in Haweswater (Westmorland). Journal of Animal Ecology 9(2): 183-188.

Thoumelin, G., L. Bodineau \& M. Wartel, 1997. Origin and transport of organic matter across the Seine estuary: fatty acids and sterol variations. Marine Chemistry 58: 59-71. 
Ulanowicz, R.E., 1986. Growth and development. Ecosystems phenomenology Springer, Verlag, New York.

Ulanowicz, R.E., 1993. Inventing the Ecoscope. In: Christensen V, Pauly D (eds), Trophic models of aquatic ecosystems. Manille, Philippines: ICLARM; ix-x.

Vander Zanden, M.J. \& J.B. Rasmussen, 1999. Primary consumer $\delta^{13} \mathrm{C}$ and $\delta^{15} \mathrm{~N}$ and the trophic position of aquatic consumers. Ecology 80: 1395-1404.

Vézina, A.F., 1989. Construction of low networks using inverse methods. In Wulff, F. \& J.G. Field (eds), Network analysis in marine ecology, Methods and applications, Coastal and Marine studies. Springer-Verlag, Berlin: 62-81 pp.

Vézina, A.F. \& M.L. Pace, 1994. An inverse model analysis of planktonic food webs in experimental lakes. Canadian Journal of Fisheries and Aquatic Sciences 51: 2034-2044.

Vézina, A.F. \& T. Platt, 1988. Food web dynamics in the ocean. I best estimates using inverse methods. Marine Ecology Progress Series 42: 269-287.

Volkman, J.K., R.B. Johns, F.T. Gillan \& G.J. Perry, 1980. Microbial lipids of an intertidal sediment, I. Fatty acids and hydrocarbons. Geochimica et Cosmochimica Acta 44: 1133-1143.

Wada, E., H. Mizutani \& M. Minagawa, 1991. The use of stable isotopes for food web analysis. Critical Reviews in Food Science and Nutrition 30: 361-371.

Wada, E., M. Terazaki, Y. Kabaya \& T. Nemoto, 1987. ${ }^{15} \mathrm{~N}$ and ${ }^{13} \mathrm{C}$ abundances in the Antartic Ocean with emphasis on the biogeochemical structure of the food web. Deep Sea Research 34: 829-841.

West, J.M., G.D. Williams, S.P. Madon \& J.B. Zedler, 2003. Integrating spatial and temporal variability into the analysis of fish food web linkages in Tijuana Estuary. Environmental Biology of Fishes 67: 297-309.

Whipple, S.J., J.S. Link, L.P. Garrison \& M.J. Fogarty, 2000. Models of predation and fishing mortality in aquatic ecosystems. Fish and Fisheries 1:22-40.

Windell, J. \& S. Bowen, 1968. Methods for study of fish diets based on analysis of stomach contents. In: Ricker, W.E. (ed), Methods for assessment of fish production in fresh waters. Third edition. Blackwell, Oxford: 219-226.

Wolff, M., V. Koch, \& V. Isaac, 2000. A Trophic Flow Model of the Caeté Mangrove Estuary (North Brazil) with Considerations for the Sustainable Use of its Resources. Estuarine, Coastal and Shelf Science 50: 789-803.

Wootton, R.J., 1990. Ecology of Teleost Fishes. Fish and Fisheries Series 1, Chapman \& Hall, London. 
Table 1. Advantages and disadvantages of each method to the characterization of estuarine food webs.

\begin{tabular}{|c|c|c|}
\hline Method & Advantages & Disadvantages \\
\hline $\begin{array}{l}\text { Stomach/gut content } \\
\text { analysis }\end{array}$ & $\begin{array}{l}\text { Give a qualitative and quantitative description of the } \\
\text { trophic relationships } \\
\text { Allow the study of the variability (intra- and interspecific, } \\
\text { spatial, temporal, linked to the size) } \\
\text { Well adapted for fish food web } \\
\text { Give information for the calculation of energy flows } \\
\text { Can be applied on all type of estuaries }\end{array}$ & $\begin{array}{l}\text { Numerous biases linked to the method (regurgitation, } \\
\text { digestion...) } \\
\text { No information on the origin of the detritic organic matter }\end{array}$ \\
\hline $\begin{array}{l}\text { Stable isotopes } \\
\delta^{15} \mathrm{~N}, \delta^{13} \mathrm{C}, \delta^{34} \mathrm{~S}\end{array}$ & $\begin{array}{l}\text { Determinate the origin of the organic matter } \\
\text { Determinate the food web base } \\
\text { Allow to calculate trophic levels }\end{array}$ & $\begin{array}{l}\text { Need to begin with the separation of the different sources } \\
\text { of organic matter } \\
\text { Difficulty to apply on detritus-based estuarine food web } \\
\text { Not very efficient on fish }\end{array}$ \\
\hline $\begin{array}{l}\text { Biochemical markers } \\
\text { Fatty acids, sterols }\end{array}$ & $\begin{array}{l}\text { Determinate the different sources of organic matter } \\
\text { Determinate the food web base }\end{array}$ & $\begin{array}{l}\text { No quantitative values } \\
\text { Difficulty to apply on detritus-based estuarine food web } \\
\text { Not efficient on fish because of the metabolization of these } \\
\text { biomakers }\end{array}$ \\
\hline
\end{tabular}




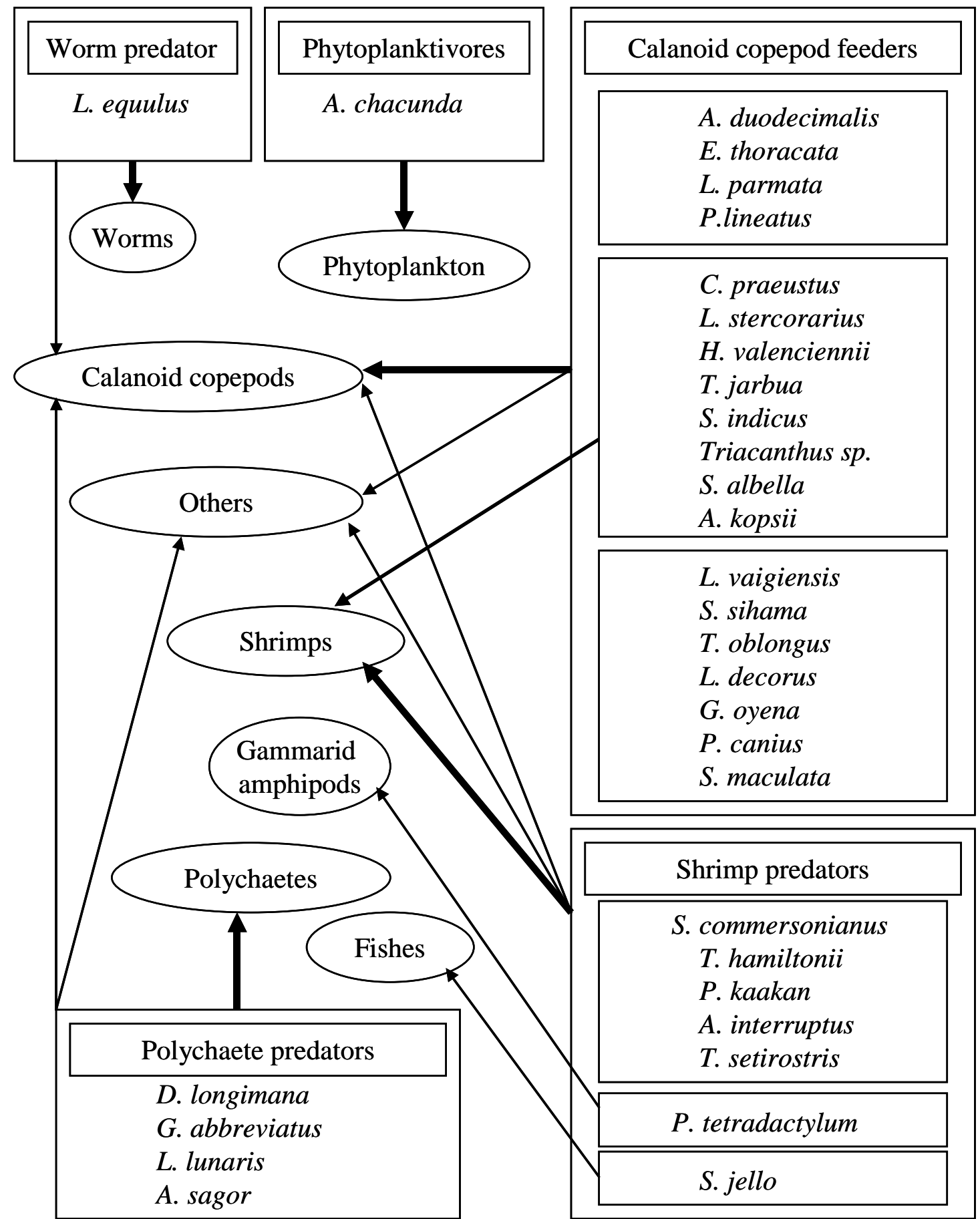

Figure 1. The overall trophic guilds of fishes in the Johor Strait (Singapor) from Hajisamae et al. (2003: 94, fig.2). 

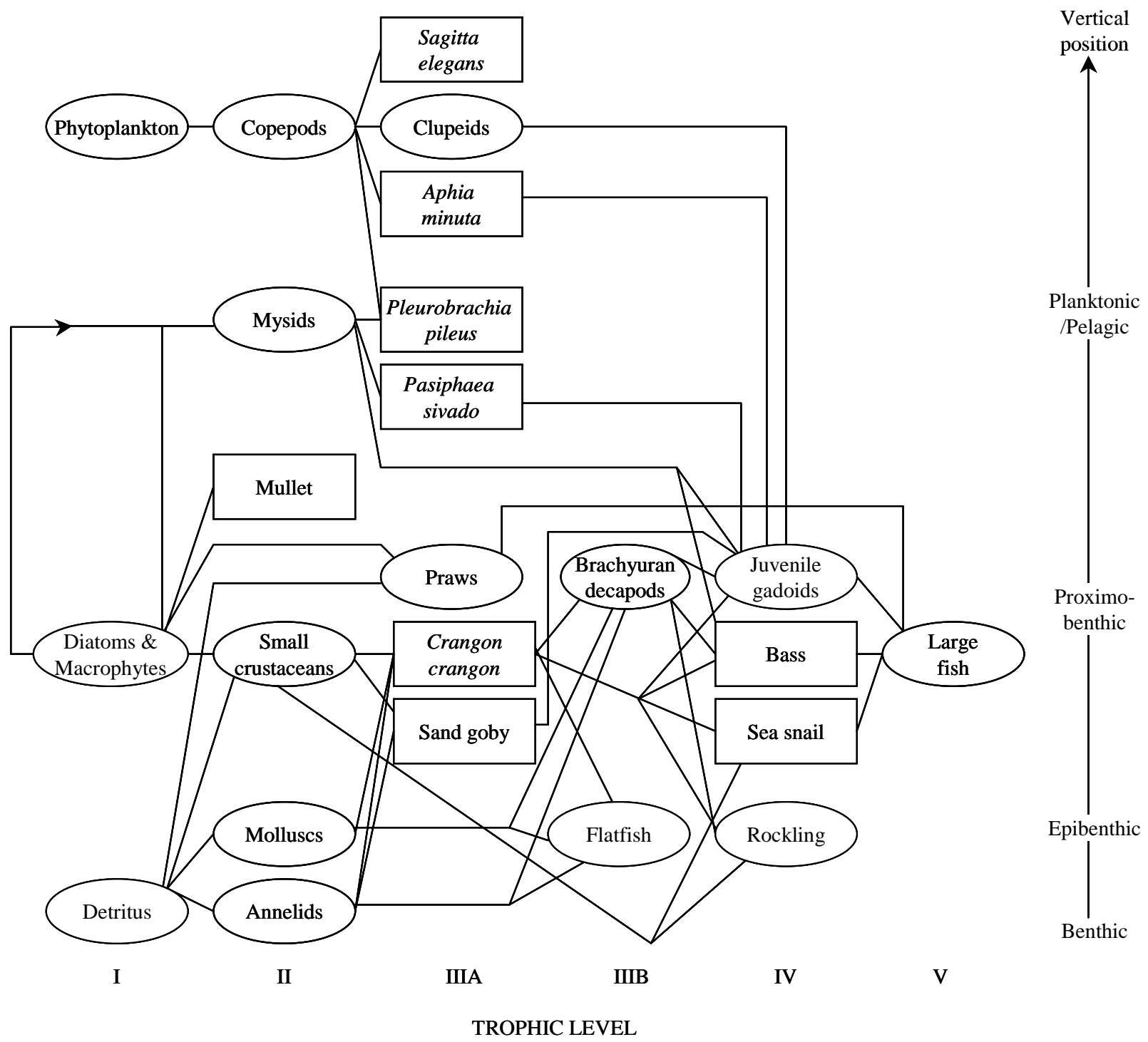

Figure 2. Generalised food web with the major trophic levels in the lower Severn estuary

(UK) from Henderson et al. (1992: 680, fig.2). 


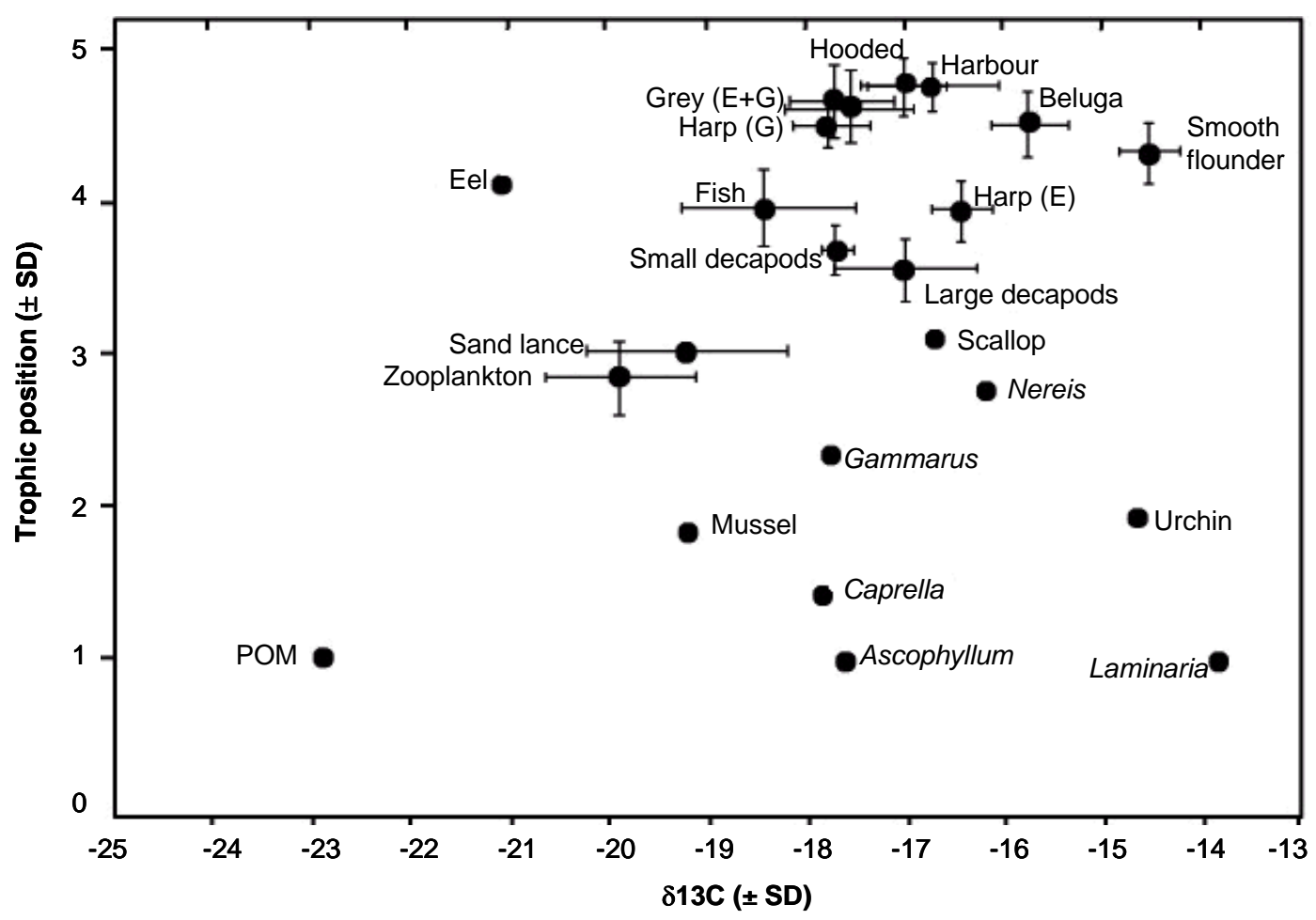

Figure 3. Trophic structure of the St Lawrence Estuary (Canada) as determined from nitrogen isotope ratios converted to trophic position and carbon isotope ratios of their different components from Lesage et al. (2001: 213, fig.4). 


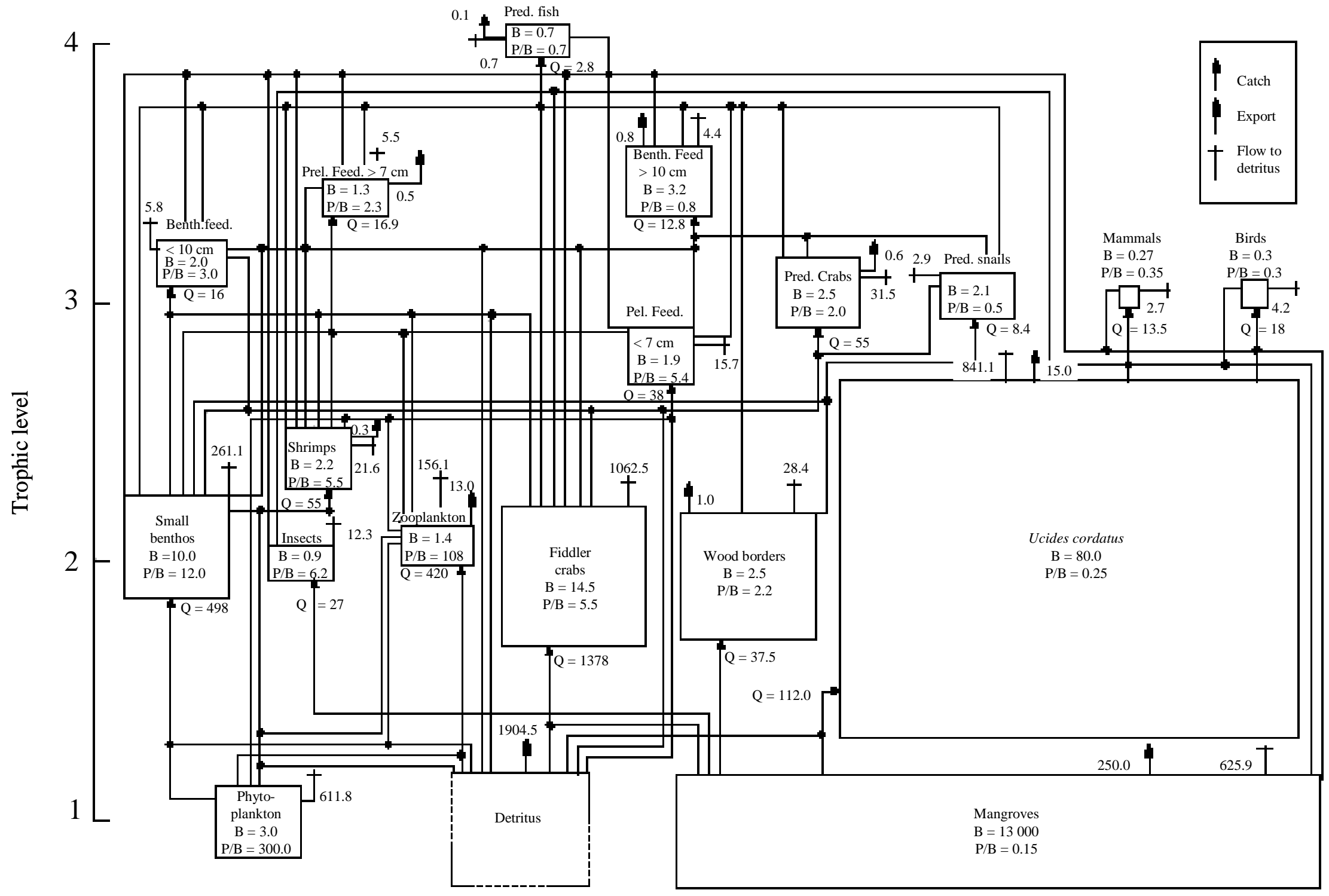

Figure 4. Trophic model of the Caeté Estuary (Brazil) from Wolff et al. (2000: 796, fig.2). 


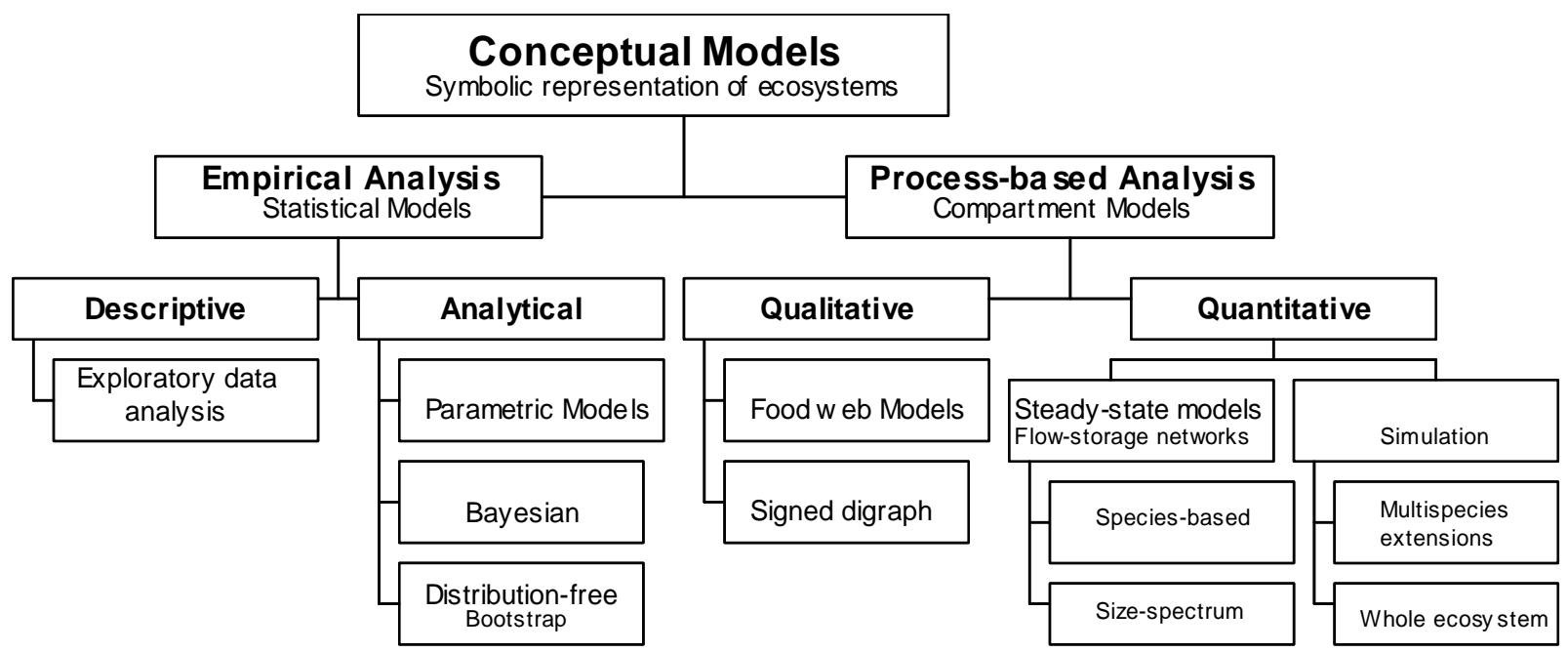

Figure 5. Diagram of the model classification by Whipple et al., 2000 